\title{
Time influence of mechanical ventilation on functional independence in patients submitted to cardiac surgery: literature review
}

\author{
Influência do tempo de ventilação mecânica sobre a \\ independência funcional em pacientes submetidos à \\ cirurgia cardíaca: uma revisão da literatura
}

\author{
André Luiz Cordeiro ${ }^{[a]}$, Thiago Araújo de Melo $^{[b]}$, Andriele Medeiros Santos ${ }^{[a]}$, \\ Gisele Freitas Lopes ${ }^{[a] *}$ \\ [a] Faculdade Nobre de Feira de Santana (FAN), Feira de Santana, BA, Brazil \\ [b] Universidade Salvador (UNIFACS), Salvador, BA, Brazil
}

\section{Abstract}

Introduction: Patients submitted to cardiovascular surgery present motor and respiratory complications mainly due to high surgery manipulation and the use of mechanical ventilation. Reducing the weaning start time and disconnecting patient's ventilation system prematurely can decrease the pulmonary complications and hospitalization time. Motor complications are the most relevant as they have a direct effect on functional independence provoked by immobility time. Objectives: Identify if mechanical ventilation time has an impact on functional capacity on patients submitted to cardiac surgery in order to contribute to the establishment of reliable evidence to practice through this patient's profile. Materials and methods:

\footnotetext{
* ALC: grad, e-mail: andrelisboacordeiro@gmail.com TAM: MSc, e-mail: agofisio@gmail.com AMS: grad, e-mail: anndry_@hotmail.com GFL: grad, e-mail: gisele_gisalopes@hotmail.com
} 
Original articles were analyzed, published between 2000 and 2014, which focused on the influence of mechanical ventilation time concerning the functional independence on patients submitted to cardiac surgery, contained in the following electronic database: Scielo, BIREME (LILACS), PubMed e CAPES. Results: It was observed that the length of stay in the intensive care unit in cardiac surgery was influenced directly by CPB, VM and pulmonary dysfunction. Functional independence was compromised in patients with longer duration of mechanical ventilation, postoperative pain and prolonged bed rest. It was also found that there is no consensus on the protocol for improved functional capacity. Conclusion: There is a functional decline in patients undergoing cardiac surgery, especially those at increased length of stay in mechanical ventilation, reflecting a direct and negative impact on their functional independence and quality of life.

Keywords: Cardiovascular surgery. Mechanical ventilation. Functional independence.

\section{Resumo}

Introdução: Os pacientes submetidos à cirurgia cardiovascular apresentam complicações motoras e respiratórias decorrentes principalmente de alta manipulação cirúrgica e do uso de ventilação mecânica. Pode-se diminuir a incidência de complicações pulmonares e o tempo de hospitalização reduzindo-se o tempo de inicio de desmame e desconectando o paciente precocemente do suporte ventilatório. As complicações motoras são as mais pertinentes, pois afetam diretamente a independência funcional pelo tempo de imobilismo. Objetivos: Identificar se existe impacto do tempo de ventilação mecânica sobre a capacidade funcional em pacientes submetidos à cirurgia cardíaca com a finalidade de contribuir com o estabelecimento de evidências confiáveis para as práticas nesse perfil de paciente. Materiais e métodos: Foram analisados artigos originais, publicados entre 2000 e 2014, que abordassem sobre a influência do tempo de ventilação mecânica sobre a independência funcional de pacientes submetidos à cirurgia cardíaca, contidas nas seguintes bases de dados eletrônicos: Scielo, BIREME (LILACS), PubMed e CAPES. Resultados: Observou-se que o tempo de permanência na unidade de terapia intensiva nas cirurgias cardíacas foi influenciado diretamente pelo tempo de CEC, VM e disfunção pulmonar. A independência funcional esteve comprometida em pacientes com maior tempo de VM, dor no pós-operatório e tempo prolongado de restrição ao leito. Também se verificou que não há consenso em relação ao protocolo para melhora da capacidade funcional. Conclusão: Existe uma declínio funcional nos pacientes submetidos a cirurgia cardíaca, principalmente naqueles em maior tempo de permanência na ventilação mecânica, refletindo de forma direta e negativa na sua independência funcional e qualidade de vida.

Palavras-chave: Cirurgia cardíaca. Ventilação mecânica. Independência funcional.

\section{Introduction}

The current cardiac surgery incidence has been increasing due to the population's daily habits, the consequence being the rise of cardiovascular diseases, mainly caused by obesity, sedentary lifestyle, smoking and systemic arterial hypertension. The physiological aging process exacerbates such factors. In Brazil's reality, these diseases occupy the leading causes of death and hospitalization, which corresponds to $32,6 \%$ of the determined cause of death (1).

Cardiovascular surgery involves high surgical manipulation, long duration, use of mechanical ventilation (MV), in addition of anesthesia, extra corporeal circulation (ECC), and chest tubes. These factors contribute to the emergence of postoperative respiratory complications such as pneumonia, pleural effusion and atelectasis. The effects of these complications in lung function may increase morbidity and mortality $(2,3)$.

According to Nogueira et al. (4), the incidence of postoperative complications is, however, a big challenge, and in a current scenario, few short-term possible solutions exists.

Even with modernization surgical procedures, several factors involved in heart surgery can compromise lung function, such as general anesthesia, surgical incision and cardiopulmonary bypass (CPB), 
leading to functional loss, that willcontribute with the limitation of daily life performance activities (3).

The invasive ventilation support is used by $39 \%$ of patients admitted to ICUs. Of these, $10 \%$ require prolonged mechanical ventilation, subject to complications associated to its use and the extended hospitalization stay (5).

Dependence on ventilatory support is directly related to morbidity occurence, and increased length of stay in the ICU, consequently a rise in the length of hospital stay occurs. Patients undergoing prolonged MV are often deconditioned and limited from a kineticfunctional point of view.

In these, several factors contribute independently to neuromuscular abnormalities: the underlying disease; the severity and duration of organ failure; the adverse effects of medications used; and, in particular, prolonged immobilization. Critically ill patients, especially those requiring mechanical ventilation, often develop acute muscle weakness, resulting in increased hospitalization rates in the ICU, readmission, physical condition reduces over a prolonged period of time, and a reduction in quality of life (5-7).

As a result of the recognized possible postoperative complications, there is a need to measure the pre and postoperative functionality, to know the dynamic of therapeutic process and intervene when necessary, fallouts not allowing the establishment of functional limitation. During heart surgery recovery, motor functional capacity is one of the most relevant aspectsas modification in patient's well-being provides alteration in other areas of life (8).

Functional independence is defined as the ability to do something with our own means. Mobility and functional capacity are related, in a way where the individual does not require assistance to its performance, e.g. independence implies motor and satisfactory cognitive conditions to perform tasks (1).

Consequently, we carried out a literature review in order to meet current and relevant information concerning the influence of prolonged mechanical ventilation and the impact on the level of functional independence in patients undergoing cardiac surgery.

\section{Materials}

Initially, electronic searches were conducted in MEDLINE databases (via PubMed), SciELO, LILACS and Peter. Other databaseswere adjusted, using publications used as a referecence such as Spanish, English and Portuguese, whose keywords were heart surgery, mechanical ventilation and functional independence.

The inclusion criteria were articles from 2000 to 2013 which focused on the influence of time in mechanical ventilation concerning the functional independence of patients submitted to cardiac surgery. Exclusion criteria for the study were articles that did not cover the topic, such as those who were unable toprovide relevant results and studies that have maintained patients in mechanical ventilation.

The selection of studies was performed by two independent observers following three steps, the first, being title reading and excluding those that clearly did not meet the established criteria. Subsequent, the selected abstracts were analyzed and those who did not meet the inclusion criteria were excluded. The final step consisted in reading full articles. An active manual search of all selected studies were also performed, using the same criteria and procedures previously described.

The articles were analyzed through the different views on our topic seeking confrontation or agreement on it.

\section{Results and Discussion}

The polyneuropathy is a very common condition developed by critical patient in intensive care units undergoing MV for more than seven days, affecting about $25.3 \%$ of patients. This worrying finding is due to the fact of neuropathy being responsible for prolonging the $\mathrm{VM}$ and the permanence of the subject in the ICU (9).

The physiotherapy treatment in patients undergoing cardiac surgery aims to avoid the negative effects of prolonged bed rest, stimulate their return to activities and prevent pulmonary complications, as well as providing a base for home care (10).

Patients submitted to HS develop, mostly PO pulmonary dysfunction with significant reduction in lung volumes, damages in respiratory function, decreased lung compliance and rises the effort to inhale. These factors, associated with immobility, pain and fear, favor the adoption of a monotonous breathing pattern without performing sporadic sighs to the total lung capacity, promoting alveolar collapse (11). 
The presence of functional decline is predictive of poor outcomes at hospital discharge and the strong correlation with prolonged hospitalization, increased mortality, increased costs and the need for home rehabilitation (12). Covinsky et al. (13), showed in a descriptive study, that functional decline experimented during hospitalization treatment for acute cases presented $35 \%$ for performing daily activities whencompared to pre hospitalization data.

Kawasaki and D'Elboux (14) while analysing data, a functional loss of $25.9 \%$ was observed, which demonstrates the high impact of immobility, critical illness and bed restriction in such a highly complex unit. In this study we evaluated the functional independence through the measurement range of functional independence (FIM) in 28 elderly patients hospitalized in a medical ward at admission. Functional loss was observed at $11.97 \%$, lower than the reduction found in this study in every five days of hospitalization, the discharge and one month following release.

In the study of Gnoatto et al.(15) the characterization of total MIF preoperatively, (97.8\%) patients presente complete independence and (2.22\%) dependence up to $25 \%$. On the $2^{\text {nd }}$ postoperative day $(60 \%)$ patients presented dependence up to $50 \%$, (38.9\%) dependence up to $75 \%$ and (1.1\%) patients with complete dependence, showing that none of the patients had functional independence in this period. On the 5 th postoperative day $(54.4 \%)$ patients presented dependence of up to $25 \%$, (41.1\%) complete independence and (4.4\%) dependence up to $50 \%$. In the preoperative period for the 2 nd postoperative day, functional loss occurred in a total of $51.09 \%$ MIF; functional loss was also observed in MIF full motor and total cognitive FIM, being $63.85 \%$ and $17.78 \%$ respectively.

In regards to the same study, in relation to the dimensions of the pre MIF for the 2nd postoperative day: in self-care functional loss was greater in the Bathroom category (83.66\%); the size transfers to higher functional loss presented in the category Transfer Toilet and Shower (77.85\%); and in Locomotion category Locomotion - Stairs showed functional loss of $83.69 \%$.

These percentages is justified by the fact that chest tube is still being used by the patient resulting in movement restriction, due to post-surgical medical guidelines and limited surgical deficit, but not by functional loss. Functional independence were not significant during the pre and $2^{\text {nd }}$ postoperative day, as there was functional loss; but were significant from the pre to the $5^{\text {th }}$ postoperative day and also on the 2nd day to the $5^{\text {th }}$ postoperative day, presenting an increase in the independence of ADLs.

In this sense Myles et al (16), observed in their study that cardiac surgery is crucial to functionality damage of these patients. The physiotherapy treatments bring metabolic exercise ends to reduce swelling and increase circulation, active exercises to maintain range of motion and gait training.

Borges et al. (7) observed in their study that the pain level had significant effect on functionality of patients undergoing cardiac surgery, both on the seventh postoperative day and at hospital discharge.

Chiang et al. (17), observed loss of peripheral muscle strength, deconditioning and decline in functional independence in mechanically ventilated patients for 14 days. They applied a physical training program for six weeks in a specialised unit in respiratory care acquiring gain in peripheral muscle strength in the arms and legs, increased days off the VM, as well as gains in functional independence measured by the FIM and Barthel score. Although Stiller (8), reports that there is still little information regarding the best type of activity to benefit critically ill patients during hospitalization and there are few published studies that explore the benefits, duration and frequency of exercise in ICU patients.

Thomsen et al. (18), reported that motor activities appear to be a significant predictor of weaning process and passive and active handlings determined as mobilization following transfer to ICU, can improve independent ambulation of the patient's pathophysiology. Although Burtin et al. (19) have demonstrated that the additional use of cycle ergometer on a daily basis to conventional physical therapy, led to an improvement in exercise capacity and self-perceived functional status at hospital discharge.

We have recently been given more attention to physical activity (beforehand) as a safe and feasible intervention in patients with neurological stability and cardio-respiratory $(20,24)$. Early mobilization includes progressive therapeutic activities such as motors exercises in bed, bedside sedestation, standing position, chair transfer and walking. Immobility, physical deconditioning and muscle weakness are common problems in patients on MV. These complications can develop into physical deconditioning in the affected individual. 
In the study by Nakamura et al. (21), with elderly patients submitted to heart surgery, a reduction in delirium index in the postoperative period with an earlier return to their homes was observed.

In another study, the hemodynamic impact of training with cycle ergometer in patients after cardiac surgery was evaluated. They said they only suffered a respiratory rate statistical variation. Confirming that the application of the cycle ergometer in patients after cardiac surgery is feasible and safe, and well accepted by patients (22).

In a study by Clavet et al. (23), one third of patients hospitalized for an extended period of time in a tertiary ICU, presented joint contractures and limitedamplitude of the entire moviment, that still lasted after two weeks of discharge. It is possible that the loss of functional independence identified is associated with decreased flexibility by muscle contractures, reduced muscle strength or other disabilities as a result from immobility.

An important factor raised by Morais et al. (3), is that patients who had a time of CPB exceeding 100 minutes showed a decrease in functionality evaluated behind the MIF.

The patient should be encouraged prematurely, through mobilization and positioning, always looking for functionality that should be emphasized from the beginning of hospitalization. Recalling that the patient should be seen as a whole, and immobility can directly affect the psychological state leading him to develop emotional disorders such as anxiety and depression that can indeed affect the functionality.

To Macchi et al. $(25,27)$ the implement of early ambulation favors a rapid recovery following surgical procedure enabling anearlier transfer of patient to rehabilitation services. Thus, the patient's walking capacity can be used as a treatment goal, as this parameter is more appropriate to the individual's functional capacity. Oliveira et al. (2) justify the significant negative correlation distance in the six-minute walk test covered with patient'speriod of hospital stay, suggesting that if the patient'shas a greater walking ability it also has a better functional capacity to discharge.

\section{Conclusion}

In our study, the functional decline was explicit in patients undergoing cardiac surgery, especially those who spent addiotional time on mechanical ventilation, having a direct and negative reflection on their functional independence and quality of life.

The studies found showed the benefits of physical therapy applied in such patients, the main purpose being the decrease of duration in mechanical ventilation and hospitalization through early mobilization, thus, minor functional losses to the patient after discharge. However, we emphasize that there is still a need for studies in the area that address the technical and its impact on the functionality of patients and studies that address the functional issue as a risk factor in ICUs.

\section{References}

1. Moraes RS, Nóbrega ACL, Castro RRT, Negrão CE, Stein R, Serra SM, et al. Diretriz de reabilitação cardíaca. Arq. Bras. Cardiol. São Paulo. May 2005;84(5).

2. de Oliveira EK, da Silva VZM, Turquetto ALR. Relação do teste de caminhada pós-operatório e função pulmonar com o tempo de internação da cirurgia cardíaca. Rev Bras Cir Cardiovasc. 2009;24(4):478-84.

3. Morais DB, Lopes ACR; Sá VM, Monteiro Júnior W, Luis Neto M. Avaliação do desempenho funcional em pacientes submetidos à cirurgia cardíaca. Rev. Bras. Cardiol. 2010;23(5):263-9.

4. Nogueira CR, Hueb W, Takiuti ME, Girardi PB, Nakano T, Fernandes F, et al. Qualidade de vida após revascularização cirúrgica do miocárdio com e sem circulação extracorpórea. Arq. Bras. Cardiol. 2008;91(4):238-44.

5. Soares TR, Avena KM, Olivieri FM, Feijó LF, Mendes KM, Filho SA, et al. Retirada do leito após a descontinuação da ventilação mecânica: há repercussão na mortalidade e no tempo de permanência na unidade de terapia intensiva? Rev. Bras. Ter. Intensiva . 2010;22(1):27-32.

6. Hodgin K, Nordon-Craft A, Mcfann KK, Mealer ML, Moss M. Physical therapy utilization in intensive care units: results from a national survey. Crit. Care Med. 2009;37(2):561-8.

7. Borges JB, Ferreira DL, Carvalho SM, Martins AS, Andrade RR, Silva MA. Avaliação da intensidade de dor e da funcionalidade no pós-operatório recente de cirurgia cardíaca. Braz J Cardiovasc Surg. 2006;21(4):393-402. 
8. Stiller K. Physiotherapy in intensive care: towards an evidence-based practice. Chest. 2000;118(6):1801-13.

9. Pinheiro AR, Christofoletti G. Fisioterapia motora em pacientes internados na unidade de terapia intensiva: uma revisão sistemática. Rev. bras. ter. intensiva. 2012;24(2):188-96.

10. Lima PMB, Cavalcante HEF, Rocha ÂRM, Brito RTF. Fisioterapia no pós-operatório de cirurgia cardíaca: a percepção do paciente. Rev Bras Cir Cardiovasc. 2011;26(2):244-9.

11. Martinez BP, Bispo AO, Duarte AC. Neto MG. Declínio funcional em uma Unidade de Terapia (UTI). Rev. Inspirar. 2013;5(1):1-5.

12. Titoto L, Sansão MS, Marino LH, Lamari NM. Reabilitação de pacientes submetidos à cirurgia de revascularização do miocárdio: atualização da literatura nacional. Arq. Ciênc. Saúde. 2005;12(4):216-19.

13. Covinsky KE, Palmer RM; Fortinsky RH,Counsell SR, Stewart AL,Kresevic D, et al. Loss of Independence in activities of daily living in older adults hospitalized with medical illnesses: increased vulnerability with age. J. Am. Geriatr Soc. 2003;51(4):451-8.

14. Kawasaki K, Kawasaki D, D'Elboux MJ. Assistência domiciliaria ao idoso: perfil do cuidador formal - parte I. Rev. esc. enferm. USP. 2001;35(3):257-64.

15. Gnoatto K, Casanova MJ, Piccoli A, Cunha PJ, Schuster RC, Leguisamo CP, et al. Capacidade funcional e dor em idosos nos períodos pré e pós-operatório de cirurgia cardíaca. ConScientiae Saúde. 2012;11(2):305-11.

16. Myles P, Hunt JO, Fletcher H, Solly R, Woodward D, Kelly S. Relation between quality of recovery in hospital and quality of life at 3 months after cardiac surgery. Anesthesiology. 2001;95(4):862-7.

17. Chiang LL, Wang LY, Wu CP, Wu HD, Wu YT. Phys Ther. 2006;86:1271-81.

18. Thomsen GE, Snow GL, Rodriguez LA, Hopkins R. Patients with respiratory failure increase ambulation after transfer to an intensive care unit where early activity is a priority. Critical Care Medicine. 2008;36(4):1119-24.

19. Burtin C, Clerckx B, Robbeets C, Ferdinande P, Langer D, Troosters T, et al. Early exercise in critically ill patients enhances short-term functional recovery. Crit. Care Med. 2009;37(9):2499-505.
20. Dantas CM, Silva PF, Siqueira FH, Pinto RM, Matias S, Maciel C, et al. Influência na mobilização precoce na força muscular periférica respiratória em pacientes críticos. Revista Brasileira de Terapia Intensiva. 2012;24(2):173-8.

21. Nakamura K, Nakamura E, Niina K, Kojim, K. Outcome after valve surgery in octogenarians and efficacy of early mobilization with early cardiac rehabilitation. Gen Thorac Cardiovasc Surg. 2010;58:606-11.

22. Cordeiro AL, Barbosa A, Araújo P, Leitão L, Carvalho S. Efeitos hemodinâmicos do treino em ciclo ergômetro em pacientes no pós-operatório de cirurgia cardíaca. Revista DERC. 2014;20(3):90-3.

23. Clavet $\mathrm{H}$, et al. Joint contracture following prolonged stay in the intensive care unit. CMAJ. 2008; 178(6):691-7.

24. Curzel J, Junior LAF, Rieder MM. Avaliação da independência funcional após alta da unidade de terapia intensiva. Rev. bras. ter. intensiva. 2013;25(2)93-8

25. Macchi C, Fattirolli F, Lova RM, Conti AA, Luisi MM, Intini R, et al. Early and late rehabilitation and physical training in elderly patients after cardiac surgery. Am J Phys Med Rehabil. 2007;86(10):826-34.

26. Bellinetti LM, Thomson JC. Respiratory muscle evaluation in elective thoracotomies and laparotomies of the upper abdomen. J Bras Pneumol. 2006;32(2):99-105.

Received: 06/21/2014 Recebido: 21/06/2014

Approved: 05/14/2015 Aprovado: 14/05/2015 